\title{
The Analysis of Organizational Capacity Factors in Government \\ Division of Regional Secretariat as A Determinant of Government \\ Performance at Batang Regency
}

\author{
Listyaningsih Dewi Pamungkas \\ Public Administration Department, Faculty of Social and Political Sciences, Diponegoro University \\ (email: listy.smg@gmail.com) \\ Kismartini \\ Retno Sunu Astuti
}

\begin{abstract}
As the leader of the implementation of governmental affairs which become the authority of regional government, based on the mandate of Law Number 23 Year 2014 on Regional Government, the Head of regional government is obliged to prepare Regional Government Administration Report (RGAR) which by the central government will be used as material for evaluation and guidance to implement the administration of regional government. Batang Regency is the only Regency which for the last respective three years (2016, 2017 and 2018) has been in the 5th rank (the lowest five) in Central Java. The results of this evaluation are used as material for the Ministry of Finance in determining the Regional Incentive Fund and for the Ministry of Home Affairs in approving additional income for state civil apparatus. However, Batang Regency has not yet optimized its reporting system and Evaluation of Regional Government Administration Performance. Due to this unoptimal evaluation results on the implementation of regional Government, organizational capacity and the evaluation of the Governmental Division at Batang Regency regional Secretariat as the division who conducted the report preparation activities became the focus of this research. Qualitative descriptive method was used to describe all the symptoms / conditions which exist during the research. Moreover, the analysis was carried out through data reduction, display data and conclusion drawing / verification. Based on the results of this research, it can be concluded that the Organizational Capacity of the Government division of the Regional Secretariat of Batang Regency which involves some resources (human resources, infrastructure, technology and financial resources) and management (leadership, program and process management as well as cooperation and relationships among organizations) needs to be improved, such as conducting job analysis, increasing the quantity and quality of human resources, making more detail activities planning and budgeting as well as defending them during budget discussions, making Terms of Reference and improving effective communication skills.
\end{abstract}

\section{Keywords:}

organizational capacity; regional government administration report; performance determinants; regional government performance 


\section{Introduction}

Batang regency as a regional government, based on the mandate of Law of the Republic of Indonesia Number 23 Year 2014 on regional Government, has implemented one of the obligations of the head of regional government to prepare Regional Government Administration Report (RGAR, in Indonesian term: Laporan Penyelenggaraan Pemerintah Daerah $[L P P D])$, Accountability Statement Reports (ASR, Indonesian term: Laporan Keterangan Pertanggungjawaban [LKPj]) and Summary of Regional Government Administration Report (RGAR), in which RGAR covers the Government Agency Performance Report (GAPR, Indonesian term: Laporan Kinerja Instansi Pemerintah (LKjIP). Moreover, RGAR will be used as the source material for the central government to conduct evaluation and guidance for regional government. Then, the results of the evaluation will be used by the Ministry of Finance as one of the bases for determining regional (regency) Incentive Fund. In addition, the Ministry of Home Affairs will also use the results of the evaluation as a consideration to approve the amount of additional income for state civil apparatus (SCA, Indonesian term: Aparatur Sipil Negara [ASN]) in the regional (regency) Government.

Batang Regency, for 3 (three) years, i.e. 2016, 2017 and 2018 respectively, has always been in the $5^{\text {th }}$ (fifth) lowest rank in the ranking of Regional Government performance status based on Central Java provincial RGAR. The complexity of the problems in making RGAR and the process of evaluating the performance of regional government along with other abundant main tasks and functions of the Government Division of the regency Regional Secretariat (Indonesian term: secretariat daerah [Setda]) has become the advantage of this research. The Government Division of Batang Regency Regional Secretariat as the leading section in writing Batang Regency Regional Government Administration Report has a significant role in reporting and evaluating the performance of regional government.

This research focused on organizational capacity of government division at the Regional Secretariat of Batang Regency which included: How were the capacity of human resources; infrastructure, technology and financial resources; strategic leadership; program and process management; cooperation and internal relations as well as relations with stakeholders in the government division at the Regional Secretariat of Batang Regency as the officers whose responsibilities for reporting and conducting evaluation of regional government performance? 


\section{Methods}

Qualitative descriptive method was used in this study to describe everything related to the performance of Batang Regency administration based on the facts, circumstances and symptoms in the research object. Qualitative descriptive research aims to describe all the symptoms / conditions which exist during the research (Nawawi \& Martini 1996: 73). This is used to conduct research on the conditions which occur at the research locus and will further describe it with the focus on what has been studied.

This study focused on the analysis of organizational capacity factors as a determinant of regional government performance. Furthermore, the locus in this study was the officers whose responsibilities for reporting and evaluating the performance of regional government administration, i.e. government division at the regional Secretariat of Batang Regency.

Organizational capacity according to Horton (2003) includes resources (human resources, infrastructure, technology and financial resources and management (leadership, program and process management as well as cooperation and relationships among organizations).

Figure 1.

Types of Organizational Capacity

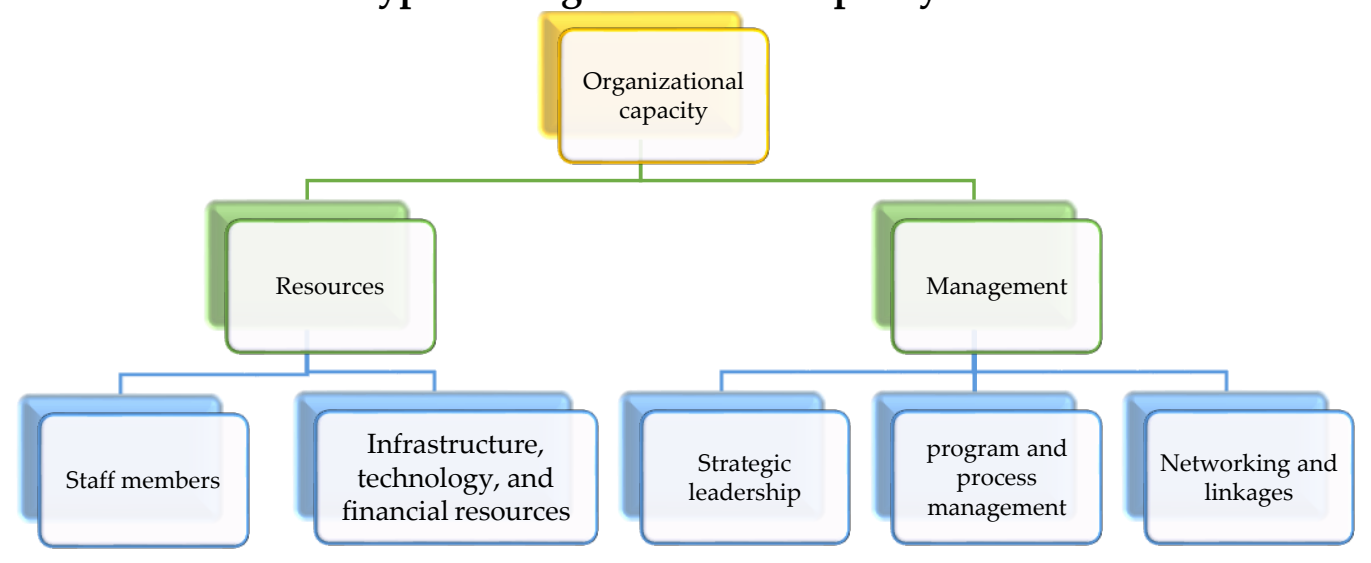

Source: Horton, 2003:24

Harel and Tzafrir (1999) formulated human resource management activities which affect organizational performance through skill development and human 
resources. In addition, there is also a model developed by Ali, Zairi and Mahat (2006) in AlDamoe (2013) stating that organizational performance is determined by 2 (two) factors, employee satisfaction and employee performance. The components of human resource or personal factors which organizational performance include knowledge, skills, abilities, self-confidence, motivation and commitment possessed by each individual (Mahmudi, 2010: 22)

Fisher, Schoenfeldt, and Shaw (1990) stated that organizations which may win the competition are those prioritizing on physical, financial, marketability, and human resources. Organizational members in working to achieve their organizational goals require both physical and non-physical supporting equipments which will support the implementation of the organization's main tasks and functions. In economics, infrastructure is a form of public capital originated from government investment (Mankiw, 2003: 38). Facilities or infrastructures are any equipment used to carry out all management activities to achieve the goals of the organization (Djoyowirono, 2005: 24). The amount of assets or capital or other financial resources owned by the government to be used or allocated to carry out any activities to achieve the goals of organization in this study is specified to one of the achievement of organizational goals related to the work performance evaluation of Batang regency government.

Leadership has an important role to direct and influence human resources to work well, to achieve organizational goals. George R. Terry in Kartono, Kartini (2006: 57) stated that leadership is a psychological process in accepting responsibility, requiring knowledge in order to carry out his duties to lead (Bangun, 2012: 337). The character of a leader is highly influenced by his communication skills, intelligence and vision.

Performance or work performance can be defined as a process of activities carried out to achieve organizational goals of which the results achieved were gained from collaborative activities among organizational components. In other words, performance is a product of administrative activities, i.e. collaborative activities done to achieve the goals whose administration is commonly referred to management. To 
achieve organizational goals with good results, it is necessary to carry out performance management through a preparation of an agreed framework of goals, standards and requirements / attributes. Performance management is defines as a process to encourage the development and improvement towards better and hiquality performance through continuous communication between leaders and employees based on the organizational goals (Suharsaputra, 2010).

Several studies showed that 'networking' affects organizational performance as conducted by Stam et al. (2006) on social capital which stated that networks as the bonds connecting companies have an effect on company performance. Research conducted by Ahuja (2000) argued that social capital in the form of networks can increase organizational innovation and has an impact on the improvement of company performance.

The data used in the research analysis consisted of primary data from primary sources obtained through in-depth interviews with informants and relevant parties and secondary data obtained from documents and records about the performance achievements of the Regional Government and other literature used to complement the research data such as from literacy studies, scientific works, printed media, journals, laws and regulations, state gazettes and other relevant sources related to the research problem. Field data collection from the informants was carried out using snowball techniques, i.e. identifying and determining the informants in the network of RGAR preparation and evaluation activities in Batang Regency. Meanwhile, Miles and Huberman model was used to analyze qualitative data, i.e. data collection, data reduction, data presentation and making conclusion.

\section{Results and Discussion}

Batang regency, one of the 35 (thirty five) Regencies / Cities in Central Java province, has 78,864.16 Ha area which is geographically located between $6^{\circ} 51^{\prime} 46^{\prime}$ and $7^{\circ} 11^{\prime} 47^{\prime}$ South Latitude and between 109 $40^{\prime} 19^{\prime}$ and 110 $03^{\prime} 06^{\prime}$ East Longitude. In addition, the border areas surrounding this regency are Java Sea (South), Kendal 
Regency (East), Wonosobo and Banjarnegara Regencies (South), Pekalongan Regency and Pekalongan City (West).

The regional government of Batang regency has 39 (thirty nine) Regional Work Units to carry out concurrent government affairs (24 functions) and optional government affairs ( 8 functions). Government division which is one of the nine divisions in the organizational structure of Batang Regency regional secretariat is the leading sector for the preparation of Regional Government Administration Report that is considered as the main material for evaluating the performance of Regional Government. The Government Division of Batang Regency Regional Secretariat has some duties, i.e. to prepare regional policy formulations, to coordinate the formulation of regional policies, to implement regional apparatus duties, to monitor and to evaluate the implementation of regional policies, to implement training and coaching to government administration, territoriality, cooperation and regional autonomy subdivisions. This division has 3 (three) Sub Divisions; they are Government Administration; Territorial Administration; Cooperation and Regional Autonomy).

One of this division main tasks is to prepare and write 3 (three) very important and strategic reports of the Regional Head (regency head or regent), i.e. Regional Government Administration Report (RGAR), Accountability Statement Report (ASR) and Summary of Regional Government Administration Reports, in which RGAR includes Government Agency Performance Report (GARP) and Summary of RGAR that should be published for public. This task is only one part of the Government Division duties which in total cover 44 detailed tasks in all Sub-Divisions in the Government division of Batang Regency Regional Secretariat.

Organizational capacity analysis of the Government division at Batang Regency Regional Secretariat as the officers in charge of reporting and evaluation of regional government performance activities whose strategic role for Regional Government involves the following aspects:

1. Human Resources 
Based on the results of the research, it shows that there is still a lack of human resources quantity in the Government division at Batang Regency Regional Secretariat compared to the details of their duties and functions. With a quite high work load and similar deadlines for several types of work (three months after the end of the fiscal year), at the end of 2019, until mid-2020, the core activities of preparing the Regional Government Administration Report will be the main material for evaluating regional government performance has just been started and the deadline is at the end of March 2020. The composition of human resources at the Government division in Batang Regency Regional Secretariat is extremely minimal. When viewed particularly from the position analysis of each technical staff assigned, i.e. 1 (one) analyst in general government and regional autonomy affairs $t$ and 2 (two) general administrators. Due to the fact that the proposal for additional human resources which has been submitted several times has not been approved and can't yet be realized, as one of the efforts to carry out the task of preparing Regional Government Administration Report of Batang Regency, the report can still be properly arranged and can eventually meet the predetermined deadlines. Thus, a steering team and an RGAR reporting team from Batang Regency Work Unit (or Indonesian term: satuan kerja perangkat daerah [SKPD]) were formed to become a team in the reporting process.

Table 1.

List of Personnel and Main Tasks and Functions of Government Division of Batang Regency Regional Secretariat

\begin{tabular}{|c|c|}
\hline $\begin{array}{l}\text { Data of the Personnel in } 2019 \\
\text { (during the arrangement of RGAR Year } \\
\text { 2019) }\end{array}$ & Main Duties \& Functions \\
\hline $\begin{array}{l}\text { Head of Government Division } \\
\text { Drs. SUPRIYONO, M.Si } \\
\text { First Class Administrator Level.I/IVb } \\
\text { Highest education: Master (S2) } \\
\text { government science }\end{array}$ & $\begin{array}{l}\text { - Formulating, coordinating the formulation of } \\
\text { regional policies, coordinating the implementation } \\
\text { of regional civil apparatus duties, monitoring and } \\
\text { evaluating the implementation of regional } \\
\text { policies, implementing the administrative } \\
\text { guidance for government administration, } \\
\text { territorial administration, and cooperation and } \\
\text { regional autonomy administration }\end{array}$ \\
\hline
\end{tabular}




\begin{tabular}{|c|c|}
\hline & $\begin{array}{l}\text { - Implementing other functions assigned by } \\
\text { government assistants and the community welfare } \\
\text { related to their duties. }\end{array}$ \\
\hline $\begin{array}{l}\text { SubDivision Government } \\
\text { Administration } \\
\text { BAMBANG SETYO HARSONO, S.IP } \\
\text { First Class Superintendent Lv.I/IIId } \\
\text { Bachelor (S1) in Political science } \\
\text { SUHARDONO } \\
\text { General administrator } \\
\text { First Class Supervisor Lv.I/IId } \\
\text { Senior High School }\end{array}$ & $\begin{array}{l}\text { - Preparing the materials for making work plans } \\
\text { and programs } \\
\text { - Preparing materials and implementing the efforts } \\
\text { to improve public services } \\
\text { - Preparing the materials for the implementation of } \\
\text { regional policies } \\
\text { - Preparing materials for the formulation of regional } \\
\text { policies } \\
\text { - Preparing materials for coordinating the } \\
\text { implementation of tasks in population and civil } \\
\text { registration, national integrity and domestic } \\
\text { politics, and peace, Public order and protection. } \\
\text { - Facilitating forum for Regional Government } \\
\text { Coordination } \\
\text { - Preparing the materials for monitoring and } \\
\text { evaluating the implementation of regional policies } \\
\text { - Coordinating the schedule of Regional (Regency) } \\
\text { house of representatives (Indonesian term-DPRD) } \\
\text { plenary meeting sessions and meetings with the } \\
\text { regional officials } \\
\text { - Coordinating, facilitating and organizing } \\
\text { ceremonial of birthday events of the Republic of } \\
\text { Indonesia, Provinces and Regencies } \\
\text { - Conducting monitoring, evaluation and } \\
\text { preparation of reports on the implementation of } \\
\text { activities to subdivision } \\
\text { - Carrying out other official duties assigned by the } \\
\text { leader/head }\end{array}$ \\
\hline $\begin{array}{l}\text { Subdivision of Territorial Administration } \\
\text { MUHAMMAD YASIN, S.STP, MM } \\
\text { First Class Superintendent Lv.I/IIId } \\
\text { Master (S2) in Management } \\
\text { SUPRAPTO } \\
\text { General Administrator } \\
\text { First Class Junior Superintendent } \\
\text { Lv.I/IIIb } \\
\text { Senior High School }\end{array}$ & $\begin{array}{l}\text { - Preparing the materials for writing work plans } \\
\text { and programs } \\
\text { - Preparing materials and implementing the efforts } \\
\text { to improve public services } \\
\text { - Conducting facilitation and coordination of the } \\
\text { formation, elimination, merging and expansion of } \\
\text { sub-districts and/or village. } \\
\text { - Conducting coordination for confirming the } \\
\text { borders of the region, sub-districts, villages and } \\
\text { other names and/or relocation of sub-district } \\
\text { capitals. } \\
\text { - Conducting facilitation for toponimy and area } \\
\text { mapping }\end{array}$ \\
\hline
\end{tabular}




\begin{tabular}{|c|c|}
\hline & $\begin{array}{l}\text { - Preparing the materials for policy on delegating } \\
\text { some of the regent's authority to the sub-district } \\
\text { heads } \\
\text { - Preparing the materials for policy on village fund } \\
\text { management } \\
\text { - Carrying out monitoring and evaluation of the } \\
\text { implementation of regional policies in territorial } \\
\text { administration } \\
\text { - Facilitating the management of village assets } \\
\text { which have turned into 'kelurahan' (village level } \\
\text { with some difference in authority, policy and } \\
\text { regulation) } \\
\text { - Facilitating problems on SubDistrict and Regency } \\
\text { borders } \\
\text { - Facilitating land issues which become regional } \\
\text { assets } \\
\text { - Carrying out monitoring, evaluation and } \\
\text { preparation of reports on the implementation of } \\
\text { activities in the sub-division } \\
\text { - Conducting other official duties given by the } \\
\text { leader/head }\end{array}$ \\
\hline $\begin{array}{l}\text { Subdivision of Cooperation and Regional } \\
\text { Autonomy } \\
\text { Drs. FAKHRUROZI } \\
\text { First Class Superintendent Lv.I/IIId } \\
\text { Bachelor (S1) in Communication } \\
\text { ETIK SUGIYARTI, S.Pd } \\
\text { Analyst in general government and } \\
\text { regional autonomy } \\
\text { First Class Supervisor Lv.I/IId } \\
\text { Bachelor (S1) in Education }\end{array}$ & $\begin{array}{l}\text { - Preparing the materials to make work plans and } \\
\text { programs } \\
\text { - Preparing materials and implementing the efforts } \\
\text { to improve public services } \\
\text { - Preparing materials for the preparation of work } \\
\text { plans and programs } \\
\text { - Preparing materials and implementing efforts to } \\
\text { improve public services } \\
\text { - Preparing the materials for making Regional } \\
\text { Government Administration Report (RGAR) and } \\
\text { Accountability Statement Report (ASR) of the } \\
\text { head of regional government (regent) } \\
\text { - Collecting Information of Regional Government } \\
\text { Administration Reports (ILPPD) } \\
\text { - Coordinating and facilitating the preparation of } \\
\text { Minimum Service Standards (Indonesian Term: } \\
\text { standar pelayanan minimal [SPM]) for regional } \\
\text { apparatus } \\
\text { - Facilitating and coordinating the process of } \\
\text { proposing the appointment and the dismissal of } \\
\text { the Regent and Vice Regent } \\
\text { - Facilitating proposal of permits and leave for the } \\
\text { Regent and vice Regent } \\
\text { - Preparing End of Service Term (EST, Indonesian } \\
\text { term: akhir masa jabatan [AMJ]) report for the } \\
\text { Regent and Vice Regent }\end{array}$ \\
\hline
\end{tabular}




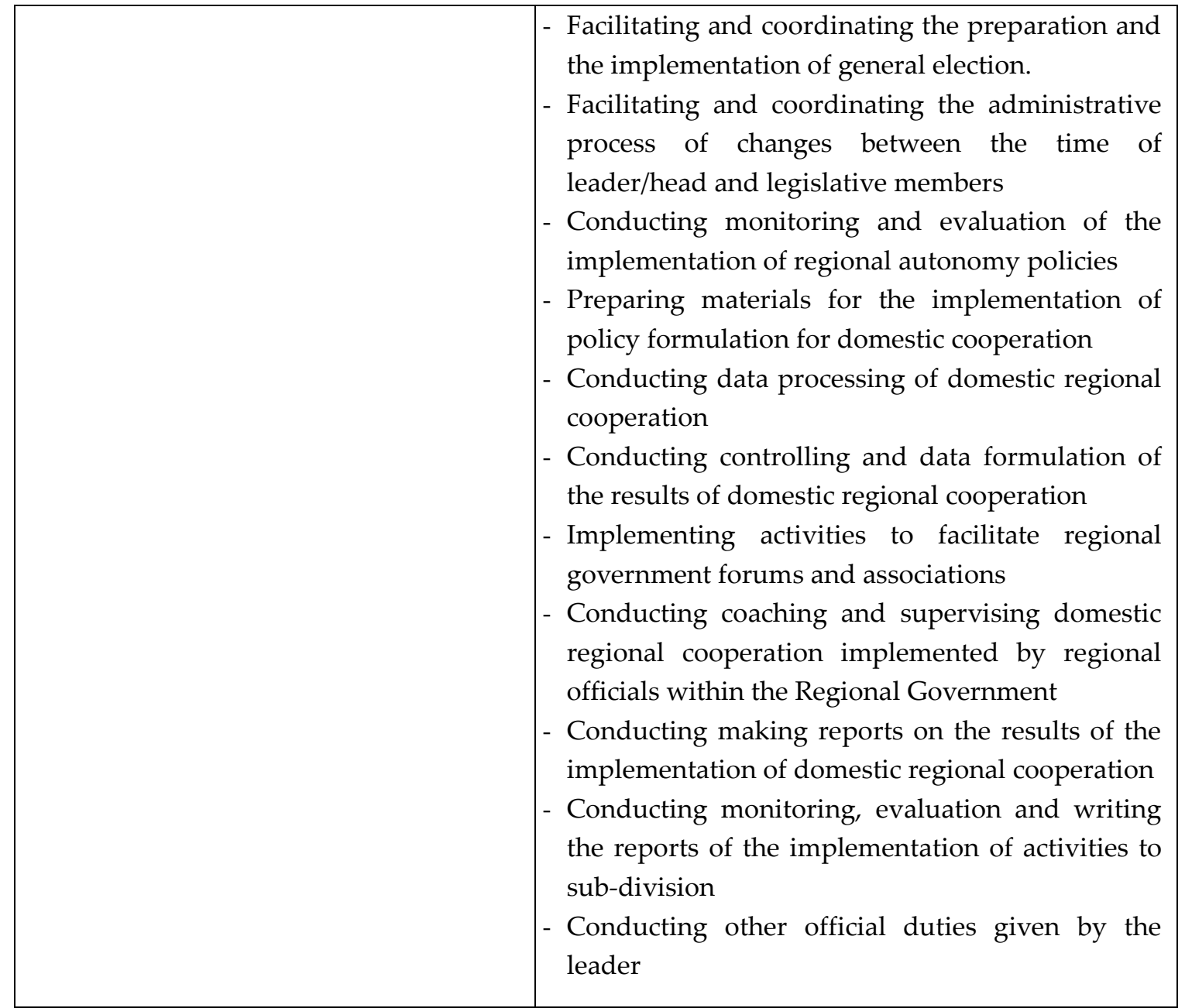

Source: Government Division Of Regional Secretariat At Batang Regency

The preparation activities of making RGAR 2019 began at the end of 2019 and the deadline was at the end of March 2020 on which the report ought to have been sent to the central government through the Governor of Central Java province. Meanwhile, the evaluation process started in around August or September. From the time span between the preparation and the evaluation process, there have been changes in the formation of human resources in the Government Division as follows:

Table 2.

Composition of Personnel in Government Division of Batang Regency Regional Secretariat

Personnel of 2019

Personnel of 2020

Head of Division

Ad interim. Head of Division 
Subdivision of Government Administration

- Head of Subdivision

- General Administrator

Subdivision of Territorial Administration

- Head of Subdivision

- General Administrator

Subdivision of Cooperation and Regional

Autonomy

- Head of Subdivision of General

Government and Regional Autonomy

Analyst
Subdivision of Government Administration

- General Administrator

- General Administrator

- General Administrator

Subdivision of Territorial Administration

- Head of Subdivision

Subdivision of Cooperation and Regional Autonomy

- General Government and Regional

Source: Government Division of Regional Secretariat at Batang Regency

Such human resource crisis conditions which occur certainly affected the quality of the work produced, as supported by the study of Mansur (2016) stating that human resource capacity affects organizational performance as it is related to the ability of the individuals, institutions or systems to carry out their functions and authorities in achieving organizational goals effectively and efficiently. According to Tjiptoherijanto (2001), as quoted by Indriasari and Nahartyo 2008), the capacity and quality of human resources can be assessed in the way they carry out their function, seen from the level of responsibility and competence of the human resources. The job description reflects responsibility since it is the basis to carry out the duties properly. Without any clear job description, these resources cannot properly carry out their duties. Furthermore, competence can be seen from educational background, trainings attended, and from the skills shown in the implementation of the tasks.

In addition to the need of conducting analysis on positions in the Government division at Batang Regency Regional Secretariat to improve human resources mapping and to submit proposals for additional human resources to the Regional 
Civil Service Agency (Indonesian term: Badan Kepegawaian Daerah [BKD]) required to approach its ideal conditions for carrying out its main duties and functions properly. If the addition of human resources with SCA status is difficult since it is related to the quota and authority of the central government, it is necessary to make some efforts to add non-SCA human resources or government employees with a work agreement (State Employee with Work Agreement or in Indonesian term Pegawai Pemerintah dengan Perjanjian Kerja [P3K]) financed by the regional government (regency) budget (Indonesian term: Anggaran Pendapatan Belanja Daerah [APBD]) which is attached to activities carried out in the Government Division.

2. Infrastructure, Technology and Financial Resources

Based on the status of the asset inventory of the Government Division at Batang Regency Regional Secretariat, it can be seen that there are still many items which are no longer usable. There has been a proposal to asset write-off but it has not yet been realized. Moreover, the results of the study show that it is urgently necessary to upgrade such assets as computer devices, internet connections, printers and digital file storage media to support the work so it can run well and without any problems.

Table 3.

Inventory of Transportation Facilities and Computer Equipment Government Division of Batang Regency Regional Secretariat

\begin{tabular}{llcl}
\hline No. & \multicolumn{1}{c}{ Types/Names of Goods } & $\begin{array}{c}\text { Years of } \\
\text { purchasing }\end{array}$ & \multicolumn{1}{c}{ Description } \\
\hline 1 & MPV car / Toyota Avanza & 2006 & Good/usable \\
2 & Motorcycle /Honda WIN MCB & 1997 & Broken \\
3 & Motorcycle /Yamaha Crypton T105 & 1999 & Broken \\
4 & Motorcycle /Honda WIN MCB & 2005 & Broken \\
5 & Motorcycle /Honda NF100 SLD & 2006 & Good/usable \\
6 & Motorcycle /Honda REVO/NF100TD & 2007 & Good/usable \\
7 & Computer /PC/Samsung & 1997 & Broken \\
\hline
\end{tabular}




\begin{tabular}{llll}
\hline 8 & Computer/PC/Samsung & 2006 & Broken \\
9 & Computer /PC/Acer & 2009 & Quite Good/usable \\
10 & Computer /PC/Samsung & 2012 & Quite Good/usable \\
11 & Computer /PC/Samsung & 2015 & Good/usable \\
12 & Computer PC/HP & 2016 & Good/usable \\
13 & Laptop/Dell & 2009 & Broken \\
14 & Laptop/Lenovo & 2011 & Broken \\
15 & Laptop/Lenovo & 2014 & Quite Good/usable \\
16 & Laptop/Lenovo & 2014 & Quite Good/usable \\
17 & Printer/Canon & 2009 & Quite Good/usable \\
18 & Printer/Canon LBP 2900 & 2010 & Quite Good/usable \\
19 & Printer & 2015 & Broken \\
20 & Printer/EPSON/L405 & 2018 & Good/usable \\
\hline
\end{tabular}

Source: Government Division Of Regional Secretariat At Batang Regency

The results of the study showed that not all the work equipment which supports the work of RGAR reporting requiring high mobility to coordinate with many agencies and the location of the agencies is within the Regent's office complex, apart from the computer equipment used to type the draft of the report as well as the digital data storage. Accordingly, regarding the currently available equipment conditions, it needs to be improved or added. Although some of the available transportation equipment and computer equipment can still be used, their performance has a lot decreased, due to their age and service life (measured from the year of purchase), most of which are more than 5 (five) years old.

It is necessary to give compensation for the personnel of RGAR reporting team as well as the data contributors from all work units to improve their performance and to give them appreciation since those who get additional assignments by becoming the RGAR reporting team must also still carry out their main duties in their own work units. Performance and attitude assessment can be done by 
comparing their contribution to work and the benefits derived from their contributions to the contributions and benefits of others (Mondy, 2008: 5).

Providing compensation will create good formal cooperative relationship between the government division and the personnel who contribute the required data from other institutions and/or agencies. Such compensation may also lead to job satisfaction because by doing additional work, they will also get additional income to meet their physical, social and egoistic needs. If the compensation given is large enough, we can get personnel with who are qualified, high motivated and consistent with the given job. Appropriate compensation can facilitate the disciplinary process since it will create greater awareness to understand the work and the valid regulations.

\section{Leadership}

Leadership is a management function. According to Koontz (1990), leadership is an art or an ability to influence others to be willing and enthusiastic in trying to achieve organizational goals (Bangun, 2012: 339). A leader's commitment to facilitate the arrangement will be useful to direct and influence all team members so that there will be a high willingness and motivation for the team members to complete the task. Ad interim person of Regional Secretary is held by Dra. Lani Dwi Rejeki, MM. who definitively served as the Inspector of Batang Regency was directly involved and concerned about the evaluation process of regional government administration besides coordinating and instructing all regional work units' leaders to assist in providing the required data as requested by the evaluator regarding the performance evaluation of Batang Regency regional government.

Leaders in carrying out human resource management functions according to Schuler, Dowling and Smart (1998) in Taufik Sadikin (2018) should achieve the objectives of human resource management. Thus, they are supposed to be able to attract, to retain and to motivate the employees. When these goals are achieved, the strategic goals of the company or organization will eventually be achieved. 
Work culture and environment which motivate and stimulate good quality performance is required to build commitment and to maintain stable relationship with the employees (Amstrong, 2003). The role of the highest leader of Batang Regency Regional Secretariat determines the success in mobilizing the commitment from unit leaders under him/her. The commitment of regional work units (SKPD) leaders as the officials in charge to implement government affairs in Batang regency needs to be improved by publishing the results of evaluation, especially those with low or moderate achievements. Consequently, it must be noted by them to improve future achievements. Thus, SKPD leader is expected to be more aware of the importance of reporting and evaluation system of regional government performance through RGAR and to possess great commitment to improve performance outcomes based on key performance indicators reported through RGAR.

\section{Program and Process Management}

To meet the work deadline, i.e. handing over RGAR to the Central Government through the Governor at a maximum of 3 (three) months after the end of the fiscal year, the work of making RGAR usually starts in December of the current fiscal year by evaluating the work process of the previous year, observing the existing potential, and correcting any shortcomings which occur in the previous the completion of the work activities to anticipate and prepare plans to conduct the reporting activities better. Administrative preparations for the arrangement of the reporting team were also carried out in December. This is conducted until RGAR could be completely written based on the technical instructions of RGAR arrangement and sent to the Governor without being late from the scheduled deadline (March 31 st).

Time schedule is arranged and implemented to organize all program activities. This aims to ensure that the work and their main tasks and functions can be carried out properly with various limited resources. The evaluation of the activities is 
carried out at the end of the fiscal year to analyze the strengths and weaknesses of last year's activities. Accordingly, any future obstacles can be minimized by anticipating or making alternative plans to overcome weaknesses in last year's activities. The results of the activities evaluation are given to higher level leader particularly to resolve problems which require special policies or the authority from the highest leader.

\section{Cooperation and Relationship among members}

The goals of the organization are impossible to achieve without any harmonious relationship among the members of the organization and with other stakeholders outside the organization. Awareness and willingness to release each individual's egos in carrying out the duties for the common interests / organizational goals will result in solid integration and cooperation in order to accomplish all the tasks and responsibilities in making Regional Government Administration Report.

The limited number of personnel in the Government Division in carrying out the work requires the involvement of all personnel regardless their position and functions in the subdivision structure. All existing personnel are to be involved to do the work with the closest deadline. The personnel who are in government analyst and regional autonomy positions carries out financial administration functions for all activities in the Government Division. Meanwhile, technical activities related to the preparation and evaluation of the RGAR were conducted by general administration personnel. During evaluation activity (August-September 2020) there should be four structural positions in the Government Division; however, only 1 (one) was filled, i.e. Head of the Territorial Administration Sub Division and structurally he did not have any main tasks and functions in the making and evaluation of the RGAR. On the contrary, he ought to lead technical and operational activities of RGAR evaluation and reporting assisted by four 
existing personnel who can fulfill the data required by the regional and central government evaluators.

Ahuja (2000) stated that a company which is within a network among organizations will affect the company performance. This is supported by Nurhajati (2010) stating that the quality of the network owned by an organization has a positive effect on the ability of the organization to develop organizational innovation and will have a positive effect on the performance of the organization. This also confirms Landry et al (2002) which found the support for network effects that increase organizational innovation and the higher the degree of organizational innovation is, the higher organizational performance will be.

Relationship among members and the relationship with the stakeholders are also determined by the level of expertise and communication skills, psychology, sociology, and anthropology. Moreover, potential problems will always exist in every relationship among humans as well as in relationships among personnel within the organization and outside the organization. For this reason, it is necessary to build motivation to willingly improve effective communication skills on each personnel of the organization.

\section{Conclusion}

Referring to the aims of this study, it can be concluded that:

1. The quantity and quality of human resources must be concerned based on job analysis and the division of tasks and functions in the work unit. The shortage of main human resources in the work units who handle the tasks including the preparation of the Regional Government Administration Report as well as the evaluation of which will result in the performance status of the Regional Government is not being optimally resolved by forming a reporting team. This is due to the fact that the team members were personnels from other work units whoso primary duties and primary responsibilities in their home work units. 
2. To achieve the organizational goals or targets set, it requires supporting infrastructure, technology and financial resources which are sufficient for the activities' needs, work demands, circumstances and times. The formulation of the Work Plan and Budget must be made in more detail because policies related to the measurement of government performance are dynamic and there is frequent rotation of officials. Therefore, socialization, consolidation and coordination activities with stakeholders need to be properly scheduled.

3. Leadership is a management process which has significant role for directing and keeping organizational members to be willing and consistent in working to achieve organizational goals. If there is any position vacuums due to a promotion or the end of the leadership's service term, the position must be immediately filled and replaced so that there will be no leadership vacuum in reporting team during the critical moments as the deadline is approaching.

4. Writing what is done and doing what we write are some ways to control the work process, so that the abundant diverse works as well as the stakeholders can be carried out coherently to achieve the goals and meet the deadlines.

5. It is necessary to develop good communication and interpersonal relationship skills to improve personal work performance which can affect the improvement of the whole organizational performance. This is because the work related to reporting and evaluation requires commitment and cooperation from all work units in the Regional Government.

Based on the research conclusions, the authors would like to recommend the followings:

1. The reporting system and the process of evaluating the performance of regional government administration are urgent matters related to the assessment of regional government performance achievements of which the results will be a consideration for the Ministry of Finance in determining the Regional Incentive Fund and the Ministry of Home Affairs in approving the amount of performance allowances for regional government employees. Consequently, it 
is urgently necessary to implement position analysis to obtain adequate quantity and quality of human resources mainly in the unit which handles the reporting task by proportionally concerning the main tasks and functions in their work units.

2. It is necessary to revise the arrangement of Work Plans and Budget in detail particularly on coordination, consultation, and compensation activities for the reporting team. In addition, during the budget discussions, the leader must be assisted by personnel who understand the details, complexity and impact of report arrangement and evaluation of regional government performance activities so that this budget plan can be explained in detail to the Regional Government Budget Team.

3. Publishing the evaluation results done by the Regional Team and the National Team for the Evaluation of Regional Government Performance to all levels of leaders in Batang Regency Government to increase the awareness of the importance to improve the performance reporting system and to build commitment to enhance their performance achievements.

4. It is necessary to prepare Terms of Reference which includes time schedule and details of the duties and responsibilities of the personnel assigned in the process of making reports and evaluation of regional government administration.

5. It is important to develop effective communication skills in the work team. This is necessary to increase good interpersonal relationships, such as by conducting non-formal interactions, being friendly, having discussions (two-way communication), paying attention and giving some appreciation on each personnel contributions in the team.

\section{References}

Ahuja G. (2000), “Collaboration Networks, Structural Holes, and Innovation: A Longitudinal Study", Administration Science Quarterly, Vol.45, pp. 425-455 
Bangun, Wilson, 2012, Manajemen Sumber Daya Manusia, Penerbit Erlangga, Jakarta

Djoyowirono, 2005, Manajemen Konstruksi Edisi Keempat, Teknik Sipil UGM, Yogyakarta

ALDamoe, Fathi M. A., Mohamd Yazam \& Kamal Ab Hamid, 2013, Human Resource Management Practices on Organizational Performance in Libya Firm, College of Business, Universiti Utara Malaysia, Malaysia Public Administration Research; Vol. 2, No. 1; 2013 ISSN 1927-517x E-ISSN 1927-5188 Published by Canadian Center of Science and Education

Fisher, C. D., Schoenfeldt, L. F. dan Shaw, J. B. (1990). Human Resource Management. Boston: Houghton Mifflin Company

Grindle, M (1997), Getting good government capacity building the public sector of developing countries, Harvard Institute for International Development, Boston

Horton, Douglas, 2003, Evaluating Capacity Development: Experiences from Research and Development Organizations around the World, ISNAR, CTA, IDRC, Canada.

Indriasari, Desi \& Erlambang Nahartyo,2008, Pengaruh Kapasitas Sumberdaya Manusia, Pemanfaatan Teknologi Informasi, Dan Pengendalian Intern Akuntansi Terhadap Nilai Informasi Pelaporan Keuangan Pemerintah Daerah (Studi Pada Pemerintah Kota Palembang dan Kabupaten Ogan Ilir. Pontianak: Simposium Nasional Akuntansi XI

Kartono, Kartini,2006, Pemimpin dan Kepemimpinan, PT. Raja Grafindo Persada, Jakarta Mankiw, Gregory N., 2003, Teori Makroekonomi, Edisi Kelima, Alih Bahasa : Imam Nurmawan, SE., Erlangga, Jakarta.

Mahmudi, 2005, Manajemen Kinerja Sektor Publik, UPP AMP YKPN, Yogyakarta Mahsun, Mohamad. 2006. Pengukuran Kinerja Sektor Publik : Cetakan Pertama. Yogyakarta : Penerbit BPFE-Yogyakarta.

Mansur, 2016, Pengaruh Kapasitas Sumber Daya Manusia Dan Pemanfaatan Teknologi Informasi Terhadap Kinerja Instansi Pemerintah (Studi pada Sekretariat Daerah Kabupaten Buton), Jurnal Studi Kepemerintahan Vol. I Bulan Maret 2016 
Mardiasmo, 2009, Akuntansi Sektor Publik. Penerbit Andi, Yogyakarta.

Nawawi, Hadari dan Martini, Mimi, 1996, Penelitian Terapan, Gadjah Mada University Press, Yogyakarta

Nurhajati, Tatiek, 2010, Model Pengembangan Kinerja Organisasi Melalui Kualitas Jejaring, Kualitas Kepercayaan Dan Inovasi, EKOBIS Vol.11, No.2, Januari 2010 : $469-477$

Stam. W, Elfring .T. (2008), “Entrepreneurial Orientation And New Venture Performance: The Moderating Role of Intra-And Extraindustry Social Capital", Academy of Management Journal, Vol. 51 ,No.1, pp. 97 - 111.

Taufik Sadikin, 2018, Pengaruh Manajemen Infrastruktur dan Manajemen Kontribusi Terhadap

Tzafrir, Shay S. 2006. A Universal Perspective For Explaining the Relationship Between HRM Practices and Firm Performance At Different Point In Time. Journal of Managerial Psychology. Vol. 21 No. 2 pp: 109-130 